\title{
BELFAST RADIOCARBON DATES IV
}

A. G. SMITH, G. W. PEARSON, and J. R. PILChER

Palaeoecology Laboratory, Queen's University, Belfast, Northern Ireland INTRODUCTION

The dating equipment and operating conditions remain essentially as previously described. All samples in this list have been counted at a filling pressure equivalent to $152 \mathrm{~cm} \mathrm{Hg}$ at $20^{\circ} \mathrm{C}$. The proportional counter has recently been re-wired, resulting in a lowering of the operating voltage. Electron-microscopic examination of the old counter wire showed considerable thickening due to the accumulation of fine dust particles. A filter is being installed in the filling line to minimize this effect. Pretreatments are as given in previous date lists unless otherwise stated.

The carbon isotope ratios reported in this list were determined on a Vacuum Generators Micromass 6 unit at the Vacuum Generators Ltd. factory. The instrument has now been installed in the Palaeoecology Laboratory. The $\delta \mathrm{C}^{13}$ for our current oxalic acid standard is $-1.989 \%$ relative to P.D.B. Mass spectrometric results have been corrected to $-1.9 \%$ for oxalic acid.

Samples in this list are from Ireland unless otherwise specified.

\section{ACKNOWLEDGMENTS}

Routine operation of the dating apparatus has been carried out by Florence Qua and Anise Colville to whom we are much indebted. We gratefully acknowledge the continued financial support of the Natural Environment Research Council. We thank the following for financial support for the dating of specific samples: The Hunterian Museum, Glasgow, The New University of Ulster, The Dundrum Field Studies Committee. We thank the archaeologists who have contributed the material described in Section I for their cooperation. A number of determinations have been made related to the work of P. Q. Dresser, Physics Dept., Trinity College, Dublin, and we thank him for contributing his comments to this list.

\section{ARCHAEOLOGIC SAMPLES}

\section{Craig na Caillich series, Perthshire, Scotland}

Peat from above and below stone-axe-working floor in blanket bog at Craig na Caillich, $3.2 \mathrm{~km} \mathrm{~N}$ of Killin, Perthshire, Scotland $\left(56^{\circ} 30^{\prime} \mathrm{N}\right.$ Lat, $4^{\circ} 20^{\prime} \mathrm{W}$ Long; Grid Ref. NN/561368). Coll. and subm. 1969 by E. W. Mackie, Hunterian Mus., Glasgow. (Ritchie, 1968). Acid pretreatment.

UB-371. Craig na Caillich, CC/2

$1.5 \mathrm{~cm}$ peat, $30 \mathrm{~cm}$ above base, underlying axe-making floor. 
UB-372. Craig na Caillich, CC/3

$1.5 \mathrm{~cm}$ peat, $35 \mathrm{~cm}$ above base, overlying axe-making floor.

General Comment (E.W.McK.): thin layer of factory debris in peat suggests this part of site was used as working floor for only a short period; the 2 measurements should date this period precisely. They compare well with date $2590 \pm 130$ B.c. (Q-430) for axe from Craig Llwyd factory from peat at Shapwick Heath, Somerset (Godwin, 1960a; R., 1960, v. 2, p. 62). Date $1144 \pm 90$ B.C. (Q-387: R., 1961, v. 3, p. 73) for quarry pits at Mynydd Rhiw factory, Caernarvonshire, refers to layer formed after end of factory activity (Houlder, 1961, pp. 121-2, 141). Date $2730 \pm 135$ B.c. (BM-281) was for charcoal assoc. with Langdale axe factory (R., 1969, v. 11, p. 288).

\section{Dundrum Nature Reserve series, Co. Down}

Samples from soil horizons, some with archaeologic material, in sand dunes in Dundrum Nature Reserve, $3.2 \mathrm{~km} \mathrm{NE}$ of Newcastle, Co. Down $\left(54^{\circ} 13^{\prime} 30^{\prime \prime} \mathrm{N} \mathrm{Lat}\right.$, 5० $52^{\prime} 30^{\prime \prime} \mathrm{W}$ Long) alt. ca. 15 to $23 \mathrm{~m}$ O.D. Subm. by N. Stephens, Dept. Geog., Queen's Univ., Belfast.

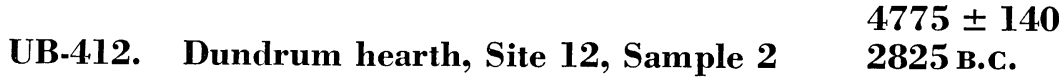

Charcoal from pebble-floored hearth; Irish Grid Ref. J 405345. Coll. 1968 by A. E. P. Collins, Archaeol. Survey of N. Ireland.

\section{UB-413. Dundrum hearth, Site 12, Sample 1}

Charcoal from same pebble-floored hearth as UB-412 above. Coll. 1967 by R. C. Davidson, Inch, Downpatrick.

\section{UB-352. Dundrum, Slidderyford Hollow $\quad \mathbf{1 6 8 5} \pm \mathbf{8 0}$}

Charcoal from fossil soil horizon exposed in side of blow-out; Irish Grid Ref. J 398341. Coll. 1969 by N. Stephens.

UB-461. Dundrum, The Cut

Modern

Charcoal from fossil soil horizon exposed in erosion gully; Irish Grid Ref. J 400340. Coll. 1970 by I. Shepherd, Dept. Geog., Queen's Univ., Belfast. Comment: presumably contaminated by modern charcoal. Soil horizon expected to be prehistoric by comparison with UB-352.

General Comment: hearth assoc. with old land surface producing plain carinated Western Neolithic bowls and worked flints (Collins, 1952; 1959). Dublin date $2860 \pm 140$ (D-51: R., 1961, v. 3, p. 34) for charcoal from occupation horizon, Grid Ref. J 409388, comparable with UB-412 and 413 , was inexplicably too young.

\section{UB-414 E. Scrabo hut circle, Co. Down}

Charcoal from wall slot of round hut on Scrabo hill $2.4 \mathrm{~km}$.

Newtownards, Co. Down $\left(54^{\circ} 34^{\prime} \mathrm{N}\right.$ Lat, $5^{\circ} 43^{\prime} 30^{\prime \prime} \mathrm{W}$ Long; Irish 
Grid Ref. J 477727) alt. ca. 150 m O.D. Coll. 1969 by A. G. Smith. Site excavated by Margaret Owens for Ards Historical Soc. Permanganate pretreatment.

UB-414 A. (Un-pretreated) $1925 \pm 100$ Comment: archaeologic evidence suggests site was occupied at transition between Bronze and Iron ages. Comparable dates from Navan, Co. Armagh (R., 1970, v. 12, p. 287-288) and Lough Gara, Co. Sligo (R., 1961, v. 3, p. 34-35). Un-pretreated sample demonstrates large error that can be due to contamination in superficial soil samples.

\section{UB-205. Mad Man's Window, Co. Antrim}

$5095 \pm 120$

3145 B.c.

Charcoal from Neolithic hearth at Mad Man's Window, $1.6 \mathrm{~km} \mathrm{E}$ of Glenarm, Co. Antrim (54 $57^{\prime} 30^{\prime \prime} \mathrm{N}$ Lat, $5^{\circ} 55^{\prime} \mathrm{W}$ Long; Irish Grid Ref. D 330150 ) alt. $11 \mathrm{~m}$ O.D. Sample from Neolithic hearth on top of large flat boulder, with Western Neolithic pottery and flints, and 2 crude rough-outs of flint axes. Coll. 1968 by M. G. L. Baillie and P. C. Woodman, Ulster Mus., Belfast. Pretreatment by nitration. Comment: hearth and artifacts are early Neolithic; date is comparable with other early Neolithic dates from N Ireland (see R., 1971, v. 13, p. 107). Hearth was in buried soil on possible wave-cut platform.

\section{Newgrange series, Co. Meath}

Samples from Neolithic passage grave site at Newgrange, $3.2 \mathrm{~km} \mathrm{E}$ of Slane, Co. Meath $\left(53^{\circ} 41^{\prime}\right.$ N Lat, $6^{\circ} 29^{\prime}$ W Long; Irish Grid Ref. O 006728). Coll. 1969 by P. Q. Dresser. (O'Kelly, 1969).

\section{UB-360. Newgrange sod layer, 1}

$$
1650 \pm 45
$$

Humic acid from upper sod layer within mound, 60 to $90 \mathrm{~cm}$ above old ground surface.

UB-361. Newgrange sod layer, 2 face.

Humic acid from basal sod layer, 5 to $20 \mathrm{~cm}$ above old ground sur-

General Comment (P.Q.D.): loose stone structure of mound was probably ineffectual in preventing penetration by younger materials. Upper sample (UB-360) may thus be too young but lower (UB-361) agrees with GRN5462 and GRN-5463 (4500 \pm 45 and $4415 \pm 40$, respectively) from construction material in roof of chamber of cairn (O'Kelly, 1969).

\section{Knowth series, Co. Meath}

Samples from Neolithic passage grave site at Knowth, $3.2 \mathrm{~km} \mathrm{E}$ of Slane, Co. Meath $\left(53^{\circ} 41^{\prime} \mathrm{N}\right.$ Lat, $6^{\circ} 30^{\prime} \mathrm{W}$ Long; Irish Grid Ref. N 996734). Coll. 1967-1969 by G. Eogan and P. Q. Dresser. (Eogan, 1968).

\section{UB-299. Knowth, 1}

$$
1200 \pm 70
$$

Charcoal from secondary occupation on summit of mound (Site 1), 
along E edge. Comment: date suggests secondary occupation was in Early Christian times.

\section{UB-318. Knowth, 2}

$4875 \pm 150$

Charcoal from scatter in soil beneath mound of small passage grave to $\mathrm{E}$ of main mound, Area 4, Sq. 43. Sample not necessarily contemporary with mound construction.

\section{UB-319. Knowth, 3}

$4795 \pm 185$

Charcoal from similar location to UB-318.

\section{B.c.}

\section{UB-357. Knowth, 4 and 5, charcoal}

Combined charcoal from Samples 4 and 5 from basal redeposited sod-like layer of mound of main passage grave; Sample 4, coll. 1969 by P. Q. Dresser from cutting 29/30, W face; Sample 5, coll. 1967 by G. Eogan, from Cutting 36.

\section{UB-358. Knowth, 5}

$6835 \pm 110$

4885 B.C.

Humic acid from basal redeposited sod-like layer of mound of main passage grave, Cutting 36 .

General Comment (P.Q.D.): UB-318, -319, and -357 are maximum only for building of megaliths. UB-358 indicates long persistence of humus in soil.

\section{Gortcorbies archaeologic series, Co. Londonderry}

Samples from Neolithic and Bronze age sites at Gortcorbies, $6.4 \mathrm{~km}$ $\mathrm{NE}$ of Limavady, Co. Londonderry (54 $54^{\circ} 30^{\prime \prime} \mathrm{N}$ Lat, $6^{\circ} 50^{\prime} \mathrm{W}$ Long; Irish Grid Ref. C 743259) alt. 273 m O.D. Sites close to valley bog from which Gortcorbies core series derive (this list). Coll. 1970 by A. G. Smith and I. C. Goddard. (May, 1938; 1950). Pretreatments by P. Q. Dresser.

UB-434 E. Gortcorbies, 1

$2080 \pm 95$

Charcoal from upper black layer between 2 stone mounds over Neolithic hearths.

UB-434 C. (humic acid)

$$
1310 \pm 75
$$

UB-435 E. Gortcorbies, 2

$$
1970 \pm 95
$$

20 B.c.

Charcoal from basal black layer between 2 stone mounds over Neolithic hearths.

UB-435 C. (humic acid)

\section{UB-436. Gortcorbies, 3}

Charcoal (including Quercus) id. by A. G. Smith, from clay below, and surrounding, large stone just outside Bronze age stone circle. 
General Comment: samples do not refer to Neolithic and Bronze age occupations and indicate Iron age occupation at sites. "Errant" sherd of Iron-age pottery was found at stone circle site by May (1938).

\section{PALAEOECOlOGIC SAMPles}

\section{Sluggan bog monolith series, Co. Antrim}

Series from organic deposits from which pollen diagram was prepared from Sluggan bog, Ballylurgan Td., $2.4 \mathrm{~km}$ NE of Randalstown, Co. Antrim (54 $46^{\prime} \mathrm{N}$ Lat, $6^{\circ} 18^{\prime} \mathrm{W}$ Long; Irish Grid Ref. J 009921) alt. 52 m O.D. Samples from 16-cm-sq. sec.; monolith adjacent to large samples used for geochemical research and dated as Sluggan series (this list). Coll. 1968 by A. G. Smith and I. C. Goddard.

UB-437. Sluggan monolith, 68 to $70 \mathrm{~cm}$ $1635 \pm 75$

Sphagnum peat. Final decline of elm pollen. Pollen Zone Boundary VIII/IX (Mitchell, 1956). Acid pretreatment.

UB-438. Sluggan monolith, 124 to $126 \mathrm{~cm}$ $2930 \pm 85$

Sphagnum peat. Marked minimum in tree pollen curve. Comment (I.G.G.): similar vegetational changes seen at this date in pollen diagram from Gortcorbies (UB-386, this list). Acid pretreatment.

\section{UB-439. Sluggan monolith, 164 to $166 \mathrm{~cm}$}

$3945 \pm 85$ 1995 B.C.

Sphagnum peat. Decline of pine pollen at Pollen Zone Boundary VII/VIII of Jessen (1949). At decline of tree-pollen curve and elm curve minimum; marked increase of heaths and peak of plantain curve suggestive of forest clearance. Acid pretreatment.

\section{UB-440. Sluggan monolith, 184 to $186 \mathrm{~cm} \quad 2230$ B.C.}

Sphagnum peat. Second decline of elm pollen. Acid pretreatment.

UB-441. Sluggan monolith, 238 to $240 \mathrm{~cm}$

$4965 \pm 75$

Sphagnum peat. At marked decline of elm and pine pollen and at level of 1st plantain pollen. Acid pretreatment.

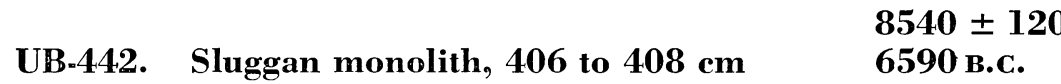

Particulate fraction of reedswamp peat with wood. Beginning of oak and elm curves at Pollen Zone Boundary V/VI.

\section{UB-443. Sluggan monolith, 426 to $428 \mathrm{~cm} \quad 7360 \pm 150$}

Particulate fraction of reedswamp peat with some wood. Marked rise of hazel curve and fall of birch curve marking Pollen Zone Boundary $\mathrm{IV} / \mathrm{V}$. 
UB-444. Sluggan monolith, 460 to $462 \mathrm{~cm}$

Particulate fraction of reedy detritus mud. Early postglacial rise of juniper pollen. Pollen Zone Boundary III/III-IV.

\section{UB-445. Sluggan monolith, 468 to $470 \mathrm{~cm}$}

Particulate fraction of fine detritus mud. Immediately above stratigraphic change from clay to organic mud. Towards end of Zone III as defined pollen analytically but base of Zone IV on lithostratigraphic grounds (cf. Jessen, 1949). Comment: by comparison with UB-444 and UB-225 F and UB-443 higher in profile, which show a consistent trend, date is too young (see comment on fractionated samples, Geochemical Samples, this list).

UB-446. Sluggan monolith, 498 to $500 \mathrm{~cm}$

$10,995 \pm 160$

Particulate fraction of fine detritus mud with some moss and reeds. Fall of birch pollen from ca. $5 \%$ to ca. $2 \%$ of total in middle of Pollen Zone II.

\section{UB-447. Sluggan monolith, 508 to $510 \mathrm{~cm}$}

$$
\begin{gathered}
11,635 \pm 160 \\
9685 \text { в.с. }
\end{gathered}
$$

Particulate fraction of fine detritus mud with some moss and reeds. Immediately above a major peak of birch pollen in lower part of Pollen Zone II.

\section{UB-448. Sluggan monolith, 514 to $516 \mathrm{~cm}$}

$$
11,040 \pm 140
$$$$
9090 \text { B.c. }
$$

Particulate fraction of fine detritus mud with some moss and reeds. Below major peak of birch pollen. Just above lower boundary of Pollen Zone II defined pollen analytically.

General Comment: complete series including samples under Geochemical Samples (R., 1970, v. 12, p. 296-297; R., 1971, v. 13, p. 124; and this list) is in sequence as follows: UB-210 A, -211 A, 437, -438-440, -219 A, -441, -220 A, -221 A, -223 D, -442, -443, -225 F, -444, -445, -227 F, -446-448, -229 F. Palynologic and other details not given previously for geochemical samples are:

UB-210 A, 42 to $47 \mathrm{~cm}$, A.D. $965 \pm 45$ and UB-211 A, 47 to $52 \mathrm{~cm}$, A.D. $725 \pm 65$. At minimum of tree pollen curve and peak of plantain pollen.

UB-219 A, 230 to $235 \mathrm{~cm}, 2700 \pm 75$ в.c. At minimum of elm and pine curves and maximum of plantain curve, immediately above Pollen Zone Boundary VII/VIII (sensu Mitchell, 1956) and VIIa/VIIb (sensu Jessen, 1949).

UB-220 A, 270 to $275 \mathrm{~cm}, 3340 \pm 65$ B.c. In middle of Zone VII (sensu Jessen, 1949).

UB-221 A, 295 to $300 \mathrm{~cm}, 4810 \pm 90$ B.c. Immediately above rise of alder curve marking Boreal-Atlantic transition, Pollen Zone Boundary VI/VII. Sample includes single grain of plantain pollen. 
UB-223 D, 365 to $370 \mathrm{~cm}, 6410 \pm 60$ в.c. Just above Pollen Zone Boundary VIa/VIb.

UB-225 F, 445 to $450 \mathrm{~cm}, 7525 \pm 145$ B.c. At rise of birch and fall of juniper curves at Pollen Zone Boundary III-IV/IV (cf. zonation at Cannon's Lough; Smith, 1961).

UB-227 F, 482 to $487 \mathrm{~cm}, 8995 \pm 145$ в.c. Broadly covers Pollen Zone Boundary II/III at top of Aller $\phi$ d deposit and immediately below clay of Younger Salix herbacea period (cf. Jessen, 1949).

UB-229 F, 515 to $520 \mathrm{~cm}, 10,520 \pm 125$ в.c. Base of Aller $\phi$ d deposit: broadly covers Pollen Zone Boundary I/II.

General Comment on samples relevant to dating of Late-Weichselian and early Flandrian pollen zone boundaries (A.G.S. and I.C.G.): Sluggan samples referring to early pollen zone boundaries are:

Zone I/II. UB-229 F: 10,520 \pm 125 B.c., comparable with Q-358: $10,000 \pm 190$ B.c., Q-359: $9895 \pm 190$ and $9880 \pm 190$ B.c. (R., 1964, v. 6 , p. 117-118) for this boundary at Roddans Port, Co. Down; indistinguishable from I-3589: $10,550 \pm 190$ в.C. (R., 1970, v. 12, p. 102) for stratigraphically similar position at Blelham Bog, $\mathrm{N}$ Lancashire (cf. Pennington and Bonny, 1970).

Zone II/III. UB-227 F: $8995 \pm 145$ B.c., is close to date expected by Godwin (1959) and tends to confirm that Q-364: $9820 \pm 190$ B.C. and Q-365: $9520 \pm 150$ (R., 1964, v. 6, p. 118) for similar horizon at Roddans Port, Co. Down are too old; supported by date for base of Younger Salix herbacea clay at Roddans Port: UB-401 C: $9200 \pm 95$ B.C. (this list).

Zone III/III-IV. UB-444: $7660 \pm 130$ в.c., dates zone boundary defined biostratigraphically, ca. $10 \mathrm{~cm}$ above lithostratigraphic boundary. Date appears somewhat younger than lithostratigraphic boundary at Scaleby Moss, Cumberland, dated by Q-151-153 (R., 1959, v. 1, p. 64-65), and early postglacial juniper rise at Blelham Bog, N Lancashire, dated by I-3598: $8540 \pm 160$ (R., 1970, v. 12, p. 103; cf. Pennington and Bonny, 1970). Date is, however, close to Q-697 for apparently similar horizon at Bigholm Burn, Dumfrieshire, $7640 \pm 170,7520 \pm 170$ в.c. (R., 1964, v. 6 , p. 120).

Zone III-IV $/ I V$. UB-225 F: $7525 \pm 140$ в.c., is younger than Q-368: $8260 \pm 150$ B.c., (R., 1964, v. 6, p. 118) Roddans Port, Co. Down, from horizon slightly higher Zone IV. Q-699: $6700 \pm 165$ B.c. is from similar pollen analytic horizon at Bigholm Burn, Dumfriesshire, but was believed too young due to contamination (R., 1965, v. 7, p. 207). Comparable dates from similar horizon at Ballynagilly, Co. Tyrone, UB-260: $7645 \pm 80$ в.C., and at Slieve Gallion, Co. Tyrone, UB-321: $7260 \pm 110$ and UB-281, $7265 \pm 75$ B.C., (R., 1971, v. 13, p. 114).

Zone $I V / V$. UB-433: $7410 \pm 150$ B.c., indistinguishable from Q-922: $7506 \pm 200$ B.C., Red Moss, Lancashire (R., 1970, v. 12, p. 593) and Q-366: $7480 \pm 150$ в.C., Roddans Port, Co. Down (R., 1964, v. 6, p. 119), at younger end of range of British dates (cf. Godwin, 1960b). 


\section{Gortcorbies series, Co. Londonderry}

Samples from 3 superposed cores, from which pollen diagram was prepared, from valley bog in Gortcorbies Td., $8 \mathrm{~km}$ WNW of Limavady, Co. Londonderry $\left(54^{\circ} 59^{\prime} \mathrm{N}\right.$ Lat, $6^{\circ} 50^{\prime} \mathrm{W}$ Long; Irish Grid Ref. C 740256 ) alt. ca. $210 \mathrm{~m}$ O.D. Coll. 1968 by A. G. Smith and I. C. Goddard. Sampling point is few hundred $\mathrm{m}$ from site of Neolithic and Beaker occupations (May, 1950; see Gortcorbies archaeologic series, this list). All samples received acid pretreatment. All sample depths are measured from bog surface.

UB-389. Gortcorbies core, 41 to $44 \mathrm{~cm}$

$730 \pm 65$

Blanket peat. Final fall of tree pollen to very low level with striking increase of grass, sedge, heath, and plantain pollen.

\section{UB-388. Gortcorbies core, 90 to $93 \mathrm{~cm}$}

$1385 \pm 65$

Blanket peat. Mid-point of fall of tree pollen curve from ca. $60 \%$ to ca. $20 \%$, immediately below tenfold increase of plantain pollen and rise of grasses and heaths.

\section{UB-387. Gortcorbies core, 158 to $161 \mathrm{~cm}$}

Blanket peat. Fall of tree pollen curve from ca. $60 \%$ to ca. $30 \%$ and fall of elm curve to insignificant values from which it never recovers (cf. Pollen Zone Boundary VIII/IX, Mitchell, 1956). Non-tree pollen, particularly of grasses, sedges, and plantains rises.

\section{UB-386. Gortcorbies core, 209 to $212 \mathrm{~cm}$}

$3025 \pm 70$ to ca. $20 \%$ at end of general fall from level of UB-385. Grass and plantain pollen increases temporarily; other weed species present.

\section{UB-385. Gortcorbies core, 243 to $246 \mathrm{~cm}$}

Highly humified reedy peat. Sample at end of presumed reedswap phase of basin and at beginning of gradual decline of tree pollen from $75 \%$ to ca. $35 \%$ just below U B-386. Heath, plantain, and other non-tree pollen rises steadily above level of sample.

\section{UB-384. Gortcorbies core, 263 to $266 \mathrm{~cm}$}

$4070 \pm 75$

Highly decayed peat with some wood. Beginning of presumed reedswamp phase of basin: decline of pine values to below 2\% (cf. Pollen Zone Boundary VII/VIII, Jessen, 1949).

\section{UB-382. Gortcorbies core, 294 to $297 \mathrm{~cm}$}

Highly decayed peat with wood and reeds. Fall of tree pollen from ca. $90 \%$ to ca. $60 \%$. Alder and elm curves decline and ash pollen appears; 
plantain and heath pollen appears in quantity, and grass pollen rises substantially.

\section{UB-237. Gortcorbies core, 312 to $315 \mathrm{~cm}$}

Highly decayed peat with wood and reeds. Rise of birch and alder curves; fall of willow, pine, and hazel curves. Total tree pollen maintained ca. $80 \%$ to $90 \%$.

UB-236. Gortcorbies core, 322 to $325 \mathrm{~cm}$

$4500 \pm 55$

2550 B.C.

Highly decayed peat with wood and reeds, containing fine charcoal fragments. Rise of birch and alder and fall of pine and willow curves: trends reverse before level of UB-237. Total tree pollen maintained at ca. $80 \%$.

UB-235. Gortcorbies core, 325 to $328 \mathrm{~cm}$

$4750 \pm 70$

2800 B.C.

Highly decayed peat with wood and reeds, containing fine charcoal fragments. Rise of pine, elm, and willow curves; fall of birch and alder curves indicate regeneration at end of land-clearance phase (cf. Stage C, Pilcher, et al., 1971).

UB-234. Gortcorbies core, 331 to $333 \mathrm{~cm}$

$5160 \pm 75$ 3210 B.C.

Highly decayed peat with wood and reeds. Elm decline, marking Pollen Zone Boundary VIIa/VIIb (Jessen, 1949) and VII/VIII (Mitchell, 1956), in progress. Curves for grasses, birch, and alder rise. Curves for pine and willow fall. Sample includes 1st plantain pollen.

UB-233. Gortcorbies core, 333 to $346 \mathrm{~cm}$

$4505 \pm 95$

2555 B.c.

Wood (Alnus) id. by I.C.G. from peat including wood from level of UB-231 (below). Comment: young date compared with adjacent peat (UB-231, -232, and -234) suggest wood is of intrusive root.

UB-232. Gortcorbies core, 334 to $336 \mathrm{~cm}$

$5115 \pm 85$

3165 B.C.

Highly decayed peat with wood and reeds, containing fine charcoal fragments. Sharp rise of sedge pollen from ca. $15 \%$ to ca. $60 \%$ of tree pollen. Immediately below beginning of elm decline. Alder and pine curves fall; willow increases.

UB-231. Gortcorbies core, 336 to $342 \mathrm{~cm}$ $5805 \pm 85$

Highly decayed peat with wood and reeds, containing fine charcoal fragments. Fall of tree pollen from ca. $95 \%$ to ca. $75 \%$; rise of pine and alder curves. Bulk of wood removed during pretreatment and incorporated in UB-233. Broadly covers Pollen Zone Boundary VI/VII, BorealAtlantic, (Jessen, 1949). 


\section{UB-230. Gortcorbies core, 365 to $368 \mathrm{~cm}$}

Highly decayed peat with wood and reeds. Sample at level of 1st appearance of oak pollen, close to Pollen Zone Boundary V/VI (Jessen, 1949).

General Comment (A.G.S. and I.C.G.): samples selected to date pollenanalytically defined stages of forest development and phases of clearance by man. As with Co. Tyrone sites Beaghmore and Ballynagilly (R., 1970, v. 12, p. 293-296), 1st indications of forest clearance are close to expansion of alder. Elm decline above $333 \mathrm{~cm}$ bracketed by UB-232 and -233 dates from ca. 3200 B.c., as at other sites. Land clearance phase of type described by Pilcher et al., 1971), starting at this level, is clearly early Neolithic and lasted some 4 centuries, shown by UB-235 at its close.

UB-236 and -237 , though separated by ca. $10 \mathrm{~cm}$ peat, are indistinguishable. Penetration by roots (UB-233, above) may have affected dates or deposition rate. Fivefold increase of deposition rate above level of UB384 relative to that below UB-235. Between these samples it may have been irregular. By comparison with adjacent samples, UB-382 appears slightly too young and it may also have contained roots. Deposition rate below UB-235 is ca. $70 \mathrm{yr} / \mathrm{cm}$ and above UB-384 is ca. $15 \mathrm{yr} / \mathrm{cm}$.

At level of UB-382: $2025 \pm 75$ B.c., marked forest clearance is indicated and appears attributable to Beaker peoples (see general comment on Ballynagilly Series I, R., 1971, v. 13, p. 105-108), but date is statistically indistinguishable from UB-384, above. Evidence for considerable Beaker activity close to site found by Herring (1938) and May (1938; 1950). UB-385: $1655 \pm 70$ в.C., dates beginning of slowly progressive deforestation which probably began in Early Bronze age (R., 1971, v. 13, p. 107), and continued until level of UB-386: $1075 \pm 70$ B.C., where agricultural activity appears much intensified. This date compares closely with that given by Eogan (1964) for Bishopsland phase of later Bronze age.

UB-387: $105 \pm 65$ B.c. is at level of extensive forest clearance, which probably occurred in Iron age. Date is indistinguishable from those of nearby charcoal layers above Neolithic hearths, UB-434 and UB-435 (this list). Massive clearance at level of UB-388: A.D. $565 \pm 65$, presumably largely for pastoralism, probably occurred in Later Iron age (Early Christian times) and final clearance at level of UB-389: A.D. $1220 \pm 65$, appears to have been in Norman times.

General comment on samples relevant to dating of Flandrian pollen zone boundaries: samples from Gortcorbies (this list) and Sluggan referring to later pollen zone boundaries are:

Zone V/VI. UB-442: $6590 \pm 120$ B.c., shows that V/VI boundary at Sluggan falls within range established for N Ireland-Q-367: $7140 \pm 150$ B.c. (Roddans Port; R., 1964, v. 6, p. 119), UB-280; $6810 \pm 90$ в.c. and UB-258: $6145 \pm 80$ в.c. (Slieve Gallion and Ballynagilly; R., 1971, v. 13, p. 112-113). Some of these determinations appear younger than determi- 
nations for zone boundary in England: Q-161: $7059 \pm 194$ (Scaleby: R., 1959, v. 1, p. 64) and Q-920: $6840 \pm 170$ B.c. (Red Moss, Lancs; R., 1970, v. 12, p. 593). UB-230: $5805 \pm 90$ B.C., which dates this zone boundary at Gortcorbies, is younger still, but comparable with Q-701: $5690 \pm 160$ B.c. (R., 1964, v. 6, p. 120) for Bigholm Burn, Dumfriesshire, Scotland, which has, however, been held in question.

Zone VI/VII. UB-221 A: $4810 \pm 90$, for Boreal-Atlantic transition at Sluggan is close to those previously obtained for N Ireland (R., 1971, v. 13, p. 124). UB-231: $3855 \pm 85$ B.C., however, which broadly covers Zone Boundary VI/VII at Gortcorbies is younger than dates previously obtained, though major rise of alder at some sites is late; e.g., just before $3345 \pm 75$ в.C., UB-93, at Beaghmore and between $3195 \pm 70$ в.C., UB253, and $3625 \pm 70$ в.C., UB-254, at Ballynagilly, Co. Tyrone (R., 1970, v. 12, p. 294-295).

Zone VIIa/VIIb (sensu Jessen, 1949, VII/VIII, sensu Mitchell, 1956). UB-441: $3015 \pm 75$ B.c., for the elm decline at Sluggan, and both UB-234: $3210 \pm 75$ в.C. and UB-232: $3165 \pm 85$ в.c. for this horizon at Gortcorbies, are close to those summarized in R., 1971, v. 13, p. 122.

Zone VIIb/VIII sensu Jessen (1949). UB-439: $1995 \pm 85$ в.c., for final pine decline at Sluggan, and UB-384, $2120 \pm 75$, for a pine decline at Gortcorbies, are indistinguishable. Both are close to UB-111: $2250 \pm$ 85 в.c. (Ballyscullion; R., 1971, v. 13, p. 110) and UB-274: $2215 \pm 80$ в.C. (Slieve Gallion; R., 1971, v. 13, p. 113). A further pine decline at Gortcorbies is dated to $1075 \pm 70$ B.C., UB-386; see also R., 1971, v. 13, p. 122.

Zone VIII/IX sensu Mitchell (1956). UB-437: A.D. $315 \pm 75$, at Sluggan, conforms with other dates for final elm decline: D-18: A.D. $340 \pm$ 120 (Agher, Co. Meath); D-29: A.D. $330 \pm 130$ (Clonsast, Co. Offaly) and D-8: A.D. $225 \pm 130$ (Redbog, Co. Louth) (R., 1961, v. 3, p. 28-30). At Gortcorbies, however, final elm decline is dated by UB-387: $105 \pm 65$ в.c. which parallels date immediately above a similar elm decline at Beaghmore, Co. Tyrone UB-87: $140 \pm 70$ B.c. (R., 1970, v. 12, p. 293). In both these cases the plantain curve rises, but does not in Mitchell's diagrams. At Gortcorbies and Beaghmore, final decline of elm thus falls in early Iron age, rather than Early Christian (Later Iron age).

\section{Foulshaw Moss series, Westmorland, England}

Sphagnum-Eriophorum-(Calluna) peat from pollen-analyzed cores of raised bog, Foulshaw Moss, Westmorland, $8 \mathrm{~km} \mathrm{NE}$ of Grange-over-Sands, N. Lancashire (54 $14^{\prime} \mathrm{N}$ Lat, $2^{\circ} 50^{\prime} \mathrm{W}$ Long; Grid Ref. SD 458837) alt. 7.6 m O.D. Coll. 1969 and subm. by F. Oldfield, School of Biol. and Env. Sci., New Univ., Ulster. All samples received acid pretreatment. (Ref. Smith, 1959; Powell, Oldfield, and Corcoran, 1971).

\section{UB-466. Foulsaw $\mathbf{5 0 6 5} \pm 100$ \\ Peass, Core III, 133 to $137 \mathrm{~cm} 3115$ B.c.}

Peat stratigraphically above Core II, but laterally displaced, less than $5 \mathrm{~cm}$ above UB-463 (below). Comment (F.O.): sample underlies decline of elm curve. Late Pollen Zone VIIa. 
UB-465. Foulshaw Moss, Core II, 0 to 3 cm

Peat. Comment (F.O.): sample at level of lime pollen maximum immediately below start of elm decline. Late Pollen Zone VIIa.

\section{UB-464. Foulshaw Moss, Core II, 3 to $6 \mathrm{~cm}$}

$4895 \pm 95$

2945 B.c.

Peat, contiguous with UB-465 (above). Comment (F.O.): sample at level of high lime pollen frequency, just below maximum. Late Pollen Zone VIIa.

\section{UB-463. Foulshaw Moss, Core II, 17 to $20 \mathrm{~cm}$}

$5380 \pm 100$

Peat. Comment (F.O.): sample $10 \mathrm{~cm}$ below level of lime pollen increase. Level correlated on basis of pollen analysis with artifacts from Storrs Moss (Powell, Oldfield, and Corcoran, 1971). Late Pollen Zone VIIa.

\section{UB-462. Foulshaw Moss, Core II, 20 to $23 \mathrm{~cm}$}

$5435 \pm 100$

Peat, contiguous with UB-463 (above). Comment (F.O.): sample 14 $\mathrm{cm}$ below level of lime pollen increase. Late Pollen Zone VIIa.

General Comment (F.O.): dates form consistent series with possible exception of UB-465, and show that early Neolithic material from Storrs Moss, correlated with present profile on basis of pollen analysis, is ca. 5400 yr. old.

\section{UB-322 D. Ballynagilly core, 376 to $380 \mathrm{~cm}$}

$9535 \pm 110$

Further sample from Ballynagilly Series II (R., 1970, v. 12, p. 294 and R., 1971, v. 13, p. 112). Particulate fraction of fine detritus mud from 376 to $380 \mathrm{~cm}$ depth in bog adjacent to "The Corbie", Ballynagilly Td., Co. Tyrone (54 $42^{\prime} \mathrm{N}$ Lat, $6^{\circ} 51^{\prime} \mathrm{W}$ Long; Irish Grid Ref. H 743837). Comment: sample taken to investigate humic acid movement in basal deposits. Date for particulate fraction is indistinguishable from date for whole peat sample, UB-260, contiguous with and below this sample. Date for humic acid is clearly younger showing movement of humic materials as found at Slieve Gallion (R., 1971, v. 13, p. 113-114).

$$
\text { UB-322 C. (humic acid) } \quad 9180 \pm 110
$$

\section{TIMBER SAMPLES}

\section{UB-343. Derrykerran South, Bog Oak 367 \\ $4985 \pm 100$ \\ 3035 в.c.}

Bog oak from Derrykerran S Td., $4.8 \mathrm{~km} \mathrm{~N}$ of Portadown, Co. Armagh (54 $28^{\prime} \mathrm{N}$ Lat, $6^{\circ} 27^{\prime} \mathrm{W}$ Long; Irish Grid Ref. J 007588) alt. ca. $24 \mathrm{~m}$ O.D. Twenty annual rings $10 \mathrm{yr}$ from outside of 350 -yr-old tree. Coll. 1968 by M. G. L. Baillie. Pretreatment by bleaching and charring. 
UB-342. Cullyhanna, Bog Oak 478

$4685 \pm 75$

2735 B.C.

Bog oak from Cullyhanna lake, $4.8 \mathrm{~km} \mathrm{~N}$ of Crossmaglen, Co. Armagh (54 ${ }^{\circ} 7^{\prime} \mathrm{N}$ Lat, $6^{\circ} 36^{\prime} 30^{\prime \prime} \mathrm{W}$ Long; Irish Grid Ref. H 915198) alt. $107 \mathrm{~m}$ O.D. Twenty annual rings, $40 \mathrm{yr}$ from outside of 120-yr-old tree. Coll. 1969 by M. G. L. Baillie. Pretreatment by bleaching and charring.

UB-417. Shanes Castle, Bog Oak 509

$3625 \pm 80$

Bog oak from Shanes Castle estate, $1.6 \mathrm{~km} \mathrm{SE}$ of Randalstown, Co. Antrim (54 $44^{\prime} 30^{\prime \prime}$ N Lat, $6^{\circ} 18^{\prime} \mathrm{W}$ Long; Irish Grid Ref. J 095897) alt. $37 \mathrm{~m}$ O.D. Twenty annual rings, $65 \mathrm{yr}$ from outside of 190-yr-old tree. Coll. 1970 by M. G. L. Baillie. Pretreatment by bleaching and charring.

\section{UB-396. Derrycrow, Bog Oak 477}

$4305 \pm 80$

Bog oak from Derrycrow Td., $10.5 \mathrm{~km} \mathrm{~N}$ of Portadown, Co. Armagh (45 $30^{\prime} 45^{\prime \prime} \mathrm{N}$ Lat, $6^{\circ} 29^{\prime} 30^{\prime \prime} \mathrm{W}$ Long; Irish Grid Ref. H 987641) alt. ca. $18 \mathrm{~m}$ O.D. From layer of oaks in peat ca. 20 to $30 \mathrm{~cm}$ above mineral soil. Coll. 1969 by A. G. S. Pretreatment by bleaching and charring. Comment: pollen and macro-remains, analyzed by $\mathrm{R}$. Todd, show that oakwood, represented by tree dated, and which replaced alder carr, was itself replaced by birch.

\section{UB-397. Ballymacombs More, Bog Oak $342 \quad 2005 \pm 80$}

Bog oak from Ballymacombs More, $13 \mathrm{~km}$ ESE of Ballymena, Co. Londonderry $\left(53^{\circ} 48^{\prime} \mathrm{N}\right.$ Lat, $6^{\circ} 28^{\prime} \mathrm{W}$ Long; Irish Grid Ref. H 987987) alt. ca. $18 \mathrm{~m}$ O.D. Sample from lower layer of stumps. Coll. 1969 by R. Todd. Pretreatment by bleaching and charring. Comment: pollen and macro-remains, analyzed by R. Todd, show sample came from 1st phase of oakwood, which succeeded alder carr, and was eventually replaced by birch.

General Comment on timber samples: 5 dates for bog oaks (UB-342, 343, 396,397 , and 417) from lowland mires from 3500 to 5000 yr B.P. One other lowland oak, UB-286, and one upland oak, UB-293, fall in same range (R., 1970, v. 13, p. 123). Concentration in this period suggests general dryness of bog surfaces.

\section{Beaghs sandpit series, Co. Antrim}

\section{GEOGHEMICAL SAMPLES}

Continuation of series from R., 1970, v. 13, p. 123-125, from W side of sand quarry in Beaghs Td., $3.2 \mathrm{~km} \mathrm{~W}$ of Cushendall, Co. Antrim $\left(55^{\circ}\right.$ $5^{\prime} \mathrm{N}$ Lat, $6^{\circ} 11^{\prime} \mathrm{W}$ Long; Irish Grid Ref. D 156276). Coll. 1969 by P. Q. Dresser.

UB-289. Beaghs sandpit, No. 3

$5135 \pm 100$

Root of pine tree from glacial deposit, 20 to $100 \mathrm{~cm}$ below blanket 
peat and directly below Sample 5 (UB-291: R., 1971, v. 13, p. 124). Pretreatment by bleaching and charring.

UB-290. Beaghs sandpit, No. 4

Modern

Rootlets impacted against iron pan $20 \mathrm{~cm}$ below basal blanket peat. Pretreatment: humic acid removal with $1 \% \mathrm{NaOH}$, acidification, washing, and charring.

\section{UB-292. Beaghs sandpit, No. 6}

$2980 \pm 80$

Her. stump, UB-291 (R., 1971, v. 13, p. 124).

\section{UB-270 E. Beaghs sandpit, No. 1}

$4155 \pm 120$

2205 B.C.

Charcoal from basal $2 \mathrm{~cm}$ layer of blanket peat (UB-270 A: R., 1971, v. 13, p. 124). Comment: sample diluted with inactive methane for counting.

General Comment (P.Q.D.): date for pine root is older than that for pine trunk in base of blanket peat ca. $30 \mathrm{~cm}$ above (UB-291: $4905 \pm 85$, R., 1971 , v. 13, p. 124), but number of annual rings in root dated was not determined; root and trunk are not certainly from different trees. These dates are both older than any fraction of basal blanket peat at site (UB270). Date for humus in sand below blanket peat (UB-292) is much younger than basal blanket peat (UB-270) demonstrating mobility of humic substances. Date for rootlets impacted on pre-peat iron pan (UB290) shows penetration from near present surface, possibly after exposure of peat face.

\section{Roddans Port series, Co. Down}

Samples from Late Weichselian deposits at Roddans Port, $17 \mathrm{~km} \mathrm{SE}$ of Newtownards, Co. Down (54 $30^{\prime} 40^{\prime \prime} \mathrm{N}$ Lat, $5^{\circ} 28^{\prime} \mathrm{W}$ Long; Irish Grid Ref. J 640658) alt. 2.4 m O.D. Deposits now exposed at low tide. Coll. 1970 by P. Q. Dresser. Site previously investigated stratigraphically and palynologically by Morrison and Stephens (1965) and extensively dated by Cambridge Lab. (R., 1964, v. 6, p. 117-119). Pollen zones given tentatively here are by stratigraphic comparison. Stratigraphy at sampling point, comparable with Point 3 of Morrison and Stephens, is:

\begin{tabular}{|c|c|}
\hline 0 to $6 \mathrm{~cm}$ & Phragmites peat \\
\hline 6 to $16 \mathrm{~cm}$ & dark brown muddy peat \\
\hline 16 to $29 \mathrm{~cm}$ & light brown muddy peat \\
\hline 29 to $103 \mathrm{~cm}$ & $\begin{array}{l}\text { gritty clay and pebbles with organic- } \\
\text { rich layers at } 95 \text { and } 100 \mathrm{~cm}\end{array}$ \\
\hline 103 to $113 \mathrm{~cm}$ & transitional peaty clay \\
\hline 113 to 160 & $\begin{array}{l}\text { light brown highly compacted organic } \\
\text { detritus mud }\end{array}$ \\
\hline t & gray sticky clay \\
\hline
\end{tabular}




\section{UB-399 A. Roddans Port, No. 2}

\section{$10,835 \pm 165$ \\ 8885 B.C.}

$\delta C^{13}=-25.6 \%$ III-IV.

Muddy peat from 26 to $29 \mathrm{~cm}$ depth. Presumed base of Pollen Zone

$$
\begin{array}{llr}
\text { UB-399 C. } \quad \text { (humic acid) } & 10,430 \pm 150 \\
& & \delta C^{13}=-26.1 \% \\
\text { UB-399 D. } & \text { (particulate }>250 \mu) & 10,190 \pm 145 \\
& \delta C^{13}=-24.8 \% \\
\text { UB-399 F. } \quad(\text { particulate }<250 \mu) & 9995 \pm 145 \\
& \delta C^{13}=-27.3 \%
\end{array}
$$

Comment (P.Q.D.): $\delta \mathrm{C}^{13}$ values are within normal range for organic deposits indicating no appreciable hard-water effect. Relative oldness of the whole sample (A) is inexplicable, as it should be a weighted mean value of the ages of the various fractions. Humic acid fraction $(\mathrm{C})$ is not younger than either of the particulate fractions as it is in some other fractionated samples; this suggests lack of movement of humic materials, though particulate fractions may contain younger rootlet material. If this is true, humic acid $(\mathrm{C})$ is more likely to provide reliable date for sample.

\section{UB-400 A. Roddans Port, No. 3}

$10,730 \pm 145$

8780 в.C.

Solifluction clay with organic content from 29 to $31 \mathrm{~cm}$ depth. Presumed top of Pollen Zone III. Sample had obvious secondary penetration by rootlets.

$$
\begin{array}{lllr}
\text { UB-400 C. } & \text { (humic acid) } & 10,380 \pm 80 \\
\text { UB-400 } & \text { D. } & \text { (particulate }>250 \mu) & 11,140 \pm 155 \\
\text { UB-400 F. } & \text { (particulate }<250 \mu) & 10,400 \pm 175 \\
& & \delta C^{13}=-24.8 \% \circ
\end{array}
$$

Comment (P.Q.D.): whole sample date (A) is acceptably within range of dates for the fractions. D fraction (solids $>250 \mu$ ) is clearly older than either of other 2 fractions and thus may contain derived material. If it does, then presumably fine particulate fraction $(\mathbf{F})$ may also contain derived material.

\section{UB-401 A. Roddans Port, No. 4}

$$
\begin{gathered}
11,390 \pm 160 \\
9440 \text { B.C. } \\
\delta C^{13}=-25.4 \%
\end{gathered}
$$

Organic layers from solifluction clay from 95 to $100 \mathrm{~cm}$ depth. Near presumed base of Pollen Zone III.

$$
\begin{array}{ccr}
\text { UB-401 C. } \quad \text { (humic acid) } & 11,150 \pm 95 \\
& & \delta C^{13}=-27.1 \% \circ \\
\text { UB-401 D. } & \text { (particulate }>250 \mu) & 11,110 \pm 125 \\
& & \delta C^{13}=-25.5 \% \\
\text { UB-401 F. } \quad(\text { particulate }<250 \mu) & 10,740 \pm 145 \\
& & \delta C^{13}=-28.2 \%
\end{array}
$$

Comment (P.Q.D.): distribution of dates is similar to that for UB-399, 
though whole sample date (A) is indistinguishable from all except fine particulate fraction (F) date. By comparison with UB-399, humic acid (C) probably provides most reliable date.

General Comment (P.Q.D.): lack of consistency of date distributions of samples probably indicates interplay of various types of error assoc. with sediments. Humic acid (C) fractions possibly more reliable than other fractions, due to their fixation by mineral ions from salt water.

\section{Sluggan series, Co. Antrim}

Series continued from R., 1970, v. 13, p. 124-125. Peat samples from Sluggan bog, Ballylurgan Td. (not Magheralane Td., as erroneously stated before), $2.4 \mathrm{~km} \mathrm{NE}$ of Randalstown, Co. Antrim (54 $46^{\prime} \mathrm{N}$ Lat, $6^{\circ} 18^{\prime} \mathrm{W}$ Long; Irish Grid Ref. J 009921) alt. ca. $52 \mathrm{~m}$ O.D. Sampling by $5.2 \mathrm{~m}$ depth excavation. Coll. 1968 by P. Q. Dresser. (See also Sluggan monolith series, this list).

\section{UB-255 A. Sluggan, No. 16, 445 to $450 \mathrm{~cm}$}

(1) $9530 \pm 140$ 7580 в.C.

(2) $9780 \pm 150$ 7830 B.c.

Muddy reedswamp peat with abundant seeds (Menyanthes) and some small twigs.
UB-225 B. (water soluble)
$8895 \pm 125$
UB-225 C. (humic acid)
$9415 \pm 130$
UB-225 D. (particulate $>250 \mu)$
$9130 \pm 135$
UB-225 F. (particulate $<250 \mu$ )
$9475 \pm 145$

Comment (P.Q.D.): dates for whole peat appear inexplicably older than any of fractions though mean of whole peat (A) determinations $(9655 \pm$ 115 ) is not significantly older than dates for fractions C and F. Relatively young dates for fractions $\mathrm{B}$ and $\mathrm{D}$ indicate mobility of water soluble materials and penetration by rootlets, respectively. Date of $\mathrm{F}$ fraction may be taken as most reliable date for sample.

\section{UB-227 A. Sluggan, No. 18, 482 to $487 \mathrm{~cm}$}

$$
\begin{gathered}
10,440 \pm 110 \\
\mathbf{8 4 9 0} \text { B.c. } \\
\delta C^{13}=-30.4 \%
\end{gathered}
$$

Fine detritus mud with some moss and reeds and a few seeds (Menyanthes).

$$
\begin{array}{llr}
\text { UB-227 C. } \quad \text { (humic acid) } & 10,795 \pm 140 \\
& & \delta C^{13}=-28.4 \% \\
\text { UB-227 D. } \quad \text { (particulate }>250 \mu) & 10,805 \pm 125 \\
& & \delta C^{13}=-30.7 \% \\
\text { UB-227 F. } \quad \text { (particulate }<250 \mu) & 10,945 \pm 145 \\
& & \delta C^{13}=-30.4 \%
\end{array}
$$

Comment (P.Q.D.): whole peat date is younger than any of fraction dates, which are themselves indistinguishable, possibly due in part to presence of younger water-soluble materials, see UB-225 above. 
$\begin{array}{ll}\text { UB-299 A. Sluggan, No. } 20,515 \text { to } 520 \mathrm{~cm} & 12,360 \pm 165 \\ \text { 10,410 B.C }\end{array}$

Fine detritus mud with some moss, seeds (Menyanthes), and reeds. Basal layer of organic deposits.
UB-229 C. (humic acid)
$11,225 \pm 160$
UB-229 D. (particulate $>250 \mu)$
$12,060 \pm 125$
UB-229 F. (particulate $<250 \mu$ )
$12,470 \pm 125$

Comment (P.Q.D.): dates for C and D fractions are younger than date for $\mathrm{F}$ fraction indicating they may contain material from higher levels. F fraction appears to provide most reliable date.

\section{Woodgrange series, Co. Down}

\section{v. GeOlogic SAMPLes}

Samples from emerged beach deposit in Woodgrange Td., $4.8 \mathrm{~km} \mathrm{~W}$ of Downpatrick, Co. Down (54 $14^{\circ} \mathrm{N}$ Lat, $5^{\circ} 47^{\prime} \mathrm{W}$ Long; Irish Grid Ref. J 438449) alt. $6.4 \mathrm{~m}$ O.D. Samples from same deposits as those dated by Isotopes (R., 1966, v. 8, p. 179) to obtain closer date bracket for beach deposit. All samples had obvious rootlet penetration. Coll. 1970 by P. Q. Dresser and A. G. Smith (Ref. Singh and Smith, 1966; Dresser, Smith and Pearson, ms. in preparation.)

UB-429. Woodgrange, 1

Upper $4 \mathrm{~cm}$ of organic layer above sand layer of beach.

\section{UB-430 A. Woodgrange, 2}

$3160 \pm 95$

1210 B.c.

$$
\delta C^{13}=-29.8 \%
$$

Basal $4 \mathrm{~cm}$ of upper layer, above sand and ca. $13 \mathrm{~cm}$ below UB-429.

$$
\begin{array}{lr}
\text { UB-430 C. } \quad \text { (humic acid) } & 3245 \pm 85 \\
& \delta C^{13}=-31.4 \% \circ \\
\text { UB-430 F. } \quad \text { (particulate }<250 \mu \text { ) } & 2900 \pm 65 \\
& \delta C^{13}=-30.5 \% \circ
\end{array}
$$

$6565 \pm 105$

\section{UB-431. Woodgrange, 3}

4615 B.c.

Uppermost part, ca. $3 \mathrm{~cm}$, of projections of eroded peaty layer below sand beach.

\section{UB-432. Woodgrange, 4}

$6770 \pm 105$

Lower part, ca. $4 \mathrm{~cm}$, of projections of eroded peaty layer below sand beach.

\section{UB-433 A. Woodgrange, 5}

Peaty material, $4 \mathrm{~cm}$ thick, contiguous with, and below, UB- 432 .
UB-433 C. (humic acid)
$6720 \pm 105$
UB-433 F. (particulate $<250 \mu$ )
$5690 \pm 85$ 
General Comment (P.Q.D. and A.G.S.): marked age difference between UB-429 and UB-430 indicates lack of physical disturbance. For both UB430 and UB-433, fine particulate fraction $(\mathrm{F})$ is younger than humic acid fraction suggesting $\mathrm{F}$ fractions contained comminuted rootlets. $\mathrm{F}$ fraction of UB-430 is probably most reliable terminus ante quem for beach and is comparable with I-1199, $3125 \pm 150$ for similar deposit. Dates for lower organic deposit do not provide close date for beginning of beach deposition because of an erosional unconformity.

\section{REFERENCES}

Collins, A. E. P., 1952, Excavations in the sandhills at Dundrum, Co. Down, 1950-51: Ulster Jour. Archaeol., v. 15, p. 2-26. 1959 , Further investigations in the Dundrum sandhills: Ulster Jour. Archaeol., v. 22, p. 5-20.

Eogan, G., 1964, The Later Bronze Age in Ireland in the light of recent research: Prehist. Soc. Proc., v. 30, p. 268-351. 1968, Excavations at Knowth, Co. Meath, 1968: Antiquity, v. 43, p. 8-14

Godwin, H., 1959, Radiocarbon dating of the Late-glacial period in Britain: Royal Soc. Proc., ser. B, v. 150, p. 199-215. 1960 a, Prehistoric wooden trackways of the Somerset Levels; their construction, age and relation to climatic change: Prehist. Soc. Proc., v. 26, p. 1-36.

1960b, Radiocarbon dating and Quaternary history in Britain: Royal Soc. Proc., ser. B, v. 153, p. 287-320.

Herring, I. J., 1938, Cairn excavation at Well Glass Spring, Largantea, Co. Londonderry: Ulster Jour. Archaeol., ser. III, v. 1, p. 164-188.

Houlder, C. H., 1961, The excavation of a Neolithic stone implement factory on Mynydd Rhiw in Caernarvonshire: Prehist. Soc. Proc., v. 27, p. 108-143.

Jessen, Knud, 1949, Studies in Late Quaternary deposits and flora-history of Ireland: Royal Irish Acad. Proc., v. 52B, p. 85-290.

May, A. McL., 1938, Burial mound, circles and cairn, Gortcobies, Co. Londonderry: Ulster Jour. Archacol., v. 1, p. 5-22.

1950, Two neolithic hearths, Gortcorbies, Co. Londonderry: Ulster Jour. Archaeol. v. 13, p. 28-39.

Mitchell, G. F., 1956, Post-Boreal pollen diagrams from Irish raised bogs: Royal Irish Acad. Proc., v. 57 B, p. 291-314.

Morrison, M. E. S. and Stephens, N., 1965, A submerged Late-Quaternary deposit at Roddans Port on the North East Coast of Ireland: Royal Soc. [London], Philos. Trans., ser. B, v. 249, p. 221-255.

O'Kelly, M. J., 1969, Radiocarbon dates for the Newgrange Passage Grave: Antiquity, v. 43 , p. 140-141.

Pennington, W. and Bonny, A. P., 1970, Absolute pollen diagram from the British Late-glacial: Nature, v. 226, p. 871-873.

Pilcher, J. R., Smith, A. G., Pearson, G. W., and Crowder, A., 1971, Land clearance in the Irish Neolithic: new evidence and interpretation: Science, v. 172, p. 560-562.

Powell, T. G. E., Oldficld, F., and Corcoran, J. X. W. P., 1971, Excavations at Storrs Moss: Prehist. Soc. Proc., in press.

Ritchie, P. R., 1968, The stone implement trade in third-millenium Scotland, in: Coles, J. M. and Simpson, D. D. A. (eds.), Studies in ancient Europe: Leicester, Leicester Univ. Press, p. 117-136.

Singh, G. and Smith, A. G., 1966, The post-glacial marine transgression in N. Irelandconclusions from estuarine and 'raised beach' deposits: a contrast: Palaeobotanist, v. 15 , p. $230-234$.

Smith, A. G., 1959, The mires of south-western Westmorland: stratigraphy and pollen analysis: New Phytol., v. 58, p. 105-127. 1961, Cannons Lough, Kilrea, Co. Derry: stratigraphy and pollen analysis: Royal Irish Acad. Proc., v. 61 B, p. 369-383. 